\title{
Subgroup and outlier detection analysis
}

\author{
Gang Wu' ${ }^{1}$ I Iwona Pawlikowska ${ }^{2}$, Tanja Gruber ${ }^{3}$, James Downing ${ }^{4}$, Jinghui Zhang ${ }^{1}$, Stan Pounds²* \\ From 12th Annual UT-ORNL-KBRIN Bioinformatics Summit 2013 \\ Buchanan, TN, USA. 22-24 March 2013
}

\section{Background}

High-dimensional biological data presents the opportunity to discover novel forms of biological heterogeneity, such as overexpression or suppression of expression of a particular gene in a subset of a cohort. This novel biological heterogeneity appears in the data as outliers or distinct subgroups. Here, we describe and evaluate three procedures for subgroup and outlier detection analysis (SODA): a leave-one-out (LOO) procedure that is widely used for outlier detection in the bioinformatics literature, the least median squares (LMS) procedure from the statistics literature, and the dip test (DT) from the statistics literature. We also propose and evaluate the max spacing test (MST) as a novel SODA method.

\section{Results}

In simulation studies, we found that LMS, DT, and MST are each the best method in specific settings. In an example analysis, we found that LMS and MST effectively identified confirmed fusion genes as outliers and DT and MST effectively identified genes that distinguish between two confirmed subtypes of pediatric acute megakaryoblastic leukemia. We conclude that LMS, DT, and MST are robust and complimentary methods for SODA.

\section{Acknowledgements}

We gratefully acknowledge funding from ALSAC which raises funds for St. Jude.

\section{Authors' details}

'Department of Computational Biology, St. Jude Children's Research Hospital, Memphis, TN 38105, USA. ${ }^{2}$ Department of Biostatistics, St. Jude Children's Research Hospital, Memphis, TN 38105, USA. ${ }^{3}$ Department of Oncology, St. Jude Children's Research Hospital, Memphis, TN 38105, USA. ${ }^{4}$ Department of Pathology, St. Jude Children's Research Hospital, Memphis, TN 38105, USA.
Published: 22 October 2013

doi:10.1186/1471-2105-14-S17-A2

Cite this article as: Wu et al:: Subgroup and outlier detection analysis. BMC Bioinformatics 2013 14(Suppl 17):A2.

\footnotetext{
* Correspondence: Stanley.pounds@stjude.org

${ }^{2}$ Department of Biostatistics, St. Jude Children's Research Hospital, Memphis, TN 38105, USA

Full list of author information is available at the end of the article
}

Submit your next manuscript to BioMed Central and take full advantage of:

- Convenient online submission

- Thorough peer review

- No space constraints or color figure charges

- Immediate publication on acceptance

- Inclusion in PubMed, CAS, Scopus and Google Scholar

- Research which is freely available for redistribution

Submit your manuscript at www.biomedcentral.com/submit

\section{() Biomed Central}

C Biomed Central

(c) 2013 Wu et al; licensee BioMed Central Ltd. This is an Open Access article distributed under the terms of the Creative Commons Attribution License (http://creativecommons.org/licenses/by/2.0), which permits unrestricted use, distribution, and reproduction in any medium, provided the original work is properly cited. 